\title{
Life is an Adventure: From Action Theory to Action ${ }^{1}$
}

\author{
Peg Brand Weiser
}

University of Arizona

\begin{abstract}
It is not a sign of weakness to follow the rules and act with respect for others; it is a sign of moral commitment (Brand, 2008b, p. 6) ${ }^{2}$
\end{abstract}

Dr. Myles N. Brand was President of the National Collegiate Athletic Association (NCAA) from January 1, 2003, until his untimely demise from pancreatic cancer on September 16, 2009, at a time when member institutions numbered 1,036 and student-athletes over 400,000 (NCAA, 2020). At this writing, NCAA institutions number 1,091, student-athletes number 504,619, and the NCAA is holding a national convention to discuss "dramatic" restructuring that may signal the end of the organization as we know it (Lederman, 2021; NCAA, 2021). It is a particularly apt time to be assessing The Myles Brand Era given that a radical change also took place when the NCAA appointed him the fourth administrator to head the institution. He was the first university president, academic, and philosopher to lead the membership in its 97-year history. How did he earn the vote of decision-makers and how did his vision make the Brand Era unique?

The authors in this special issue look back upon Brand's tenure at the NCAA, noting the rationale for his decisions, the lasting import of his actions, and the implications of his legacy going forward. I am grateful to the authors whose time and scholarship serve to complete a fuller picture of a moral philosopher, principled president, and consensus-building leader whose concern for the welfare of student-athletes was deep and personal. I am particularly motivated to respond to a comment made by David Wiggins (in this special issue) who notes, "Brand seemed to be decidedly different than the organization's other Presidents" and then remarks, "what seems most important is to ascertain what accounted for Brand's commitment to diversity, inclusiveness, and social justice." Brand argued vociferously that "There is no better place to learn life skills than athletics" (Brand, 2008a) and that good sportsmanship and competition, as quoted above, embodied a moral commitment to both the rules of the game and a respect for others. These were only two of the many ways he invested positive values learned from his academic training into rhetoric advocating athletic competition: an atypical pitch from a philosopher. 
Since nearly every author has noted Brand's academic background and training, and some have even provided partial answers to Wiggins' query, I - as a fellow philosopher - offer to track the progression of Brand's early work in action theory, his theoretical turn to the moral role of education, and finally his legacy of principled leadership on issues of ethics and social justice within intercollegiate athletics. I call this progression "from action theory to action." I hope to show that Brand's writings and speeches from 1970 through 2002 offer a foundation for the conceptual strategies employed in meeting NCAA challenges from 2003 through 2009. "Action theory + Aristotle $=$ Applied Philosophy" provides the key to his innovative conceptualization of the applied philosophy of sport that moved him forward into action.

Myles' motto was always "Life is an adventure." He invoked it when-prior to cell phones and without wilderness guides - he canoed long distances in the Northwest Territories and bushwhacked on horseback in Alaska. He raised it when attempting to convince me (in 31 years of marriage) and my stepson, Josh Brand, to move cross-country where the challenge of a new university position awaited. "You have to be willing to take interesting opportunities when they arrive and take the risks that come with them," he once said in an interview (Lawrence, 2006, pp. 7273). When it came to "adventure," the Brand Era at the NCAA did not disappoint.

\section{From Action Theory to Applied Philosophy}

Myles Neal Brand was born in Brooklyn on May 17, 1942, and educated in New York schools and universities. In interviews, he relates how he grew up in a lower middle-class environment where neither parent had attended college and he discovered books, on his own in fifth or sixth grade, at the community library (Gray, 2008). It was during the Sputnik era, and he read material that fed his interest in math and science and nurtured a "love of learning." He also played handball and stickball in the streets (Scarpino, 2007). He attended Carle Place High School on Long Islandafter the family had relocated - where he was bored and only enjoyed playing sports: basketball and track (Gray, 2008). He never thought of himself as a leader in any capacity in high school (Scarpino, 2007). Eager to get to college in 1960 and become a mechanical engineer based on summer jobs as a draftsman, he chose a school in upstate New York-Rensselaer Polytechnic Institute (RPI). After his freshman year, he spent three months designing (on paper) the mechanism to make an employee punch card pop back up after it was pushed into a machine that recorded work hours and created paychecks. (It was the early 1960s when data processing equipment was new.) "It was at that point I realized I don't really want to do this," and by the end of his sophomore year, without much guidance, he noticed that the majority of books on his shelf were philosophy (Gray, 2008, p. 2). He fondly recalled a professor, Robert E. Whalen, who was responsible for "a turning point:"

[He] literally changed my life by opening up possibilities that I didn't know existed . . . he introduced me to a world of abstract ideas that just thrilled me and excited me to a degree I had never experienced . . . It has stuck with me because it made me realize how important teachers are and what faculty 
members can accomplish in working with young people (Lawrence, 2006, p. 57).

Trained as an undergraduate engineer to solve problems pragmatically and efficiently, his thought processes - later in life, when he was in leadership positions - differed from those of philosophers who might leisurely ponder a theoretical issue free of the pressure of departmental colleagues and upper-level administrators awaiting a decision. At RPI, Brand became the head of Rensselaer Magazine but he mostly enjoyed learning and talking with fellow students (Scarpino, 2007). He earned a Bachelor of Science in Philosophy from RPI in 1964 which taught him rigor and hard work that guided him to success in graduate school. At the time, however, he thought that he might not be able to advance in a philosophy career due to anti-Semitism notable within academic philosophy (Gray, 2008).

Completing his Ph.D. in philosophy in two and a half years in 1967 at the University of Rochester under the guidance of Richard Taylor and Keith Lehrer, Brand began the typical career trajectory of teaching, writing, and publishing, with his first job at the top philosophy department in the country (Pittsburgh) and as a traditional member of the national organization of the American Philosophical Association. Within only four years (at age 29), he advanced into a series of administrative jobs with his first appointment as Assistant Chair of Philosophy, University of Pittsburgh (1971-1972); Chair of Philosophy, University of Illinois at Chicago (1972-1981); Chair of Philosophy, University of Arizona (1981-1983); Dean of Social and Behavioral Sciences, University of Arizona (1983-1986); Provost, The Ohio State University (1986-1989); President, University of Oregon (1989-1994); and President of eight campuses of Indiana University (1994-2002). He continued to teach and write but pursued administrative positions because they afforded him the opportunity to accomplish change for students and faculty alike. Moreover, he enjoyed them. Of his presidency at Indiana University he said, "I think the part I enjoyed most was working with the leadership team in formulating our goals and working to get it done" (Lawrence, 2006, p. 68). The comradery of a group - a team-appealed to him, in contrast to the solitary activity of writing philosophy, alone, at home (see Josh Brand's essay in this volume). In effect, he eventually turned his love of "abstract ideas" - the philosophical study of action theory-into action. He set goals and worked to achieve them; both activities involved debate and through leadership, consensus. Over the course of his career, he repeatedly demonstrated the influence of engineering training and graduate study in philosophy that influenced his method of communal problem-solving.

Brand began his academic career as an analytic philosopher engaged with metaphysics in an area known as action theory. His early work focused on defining an action analyzed into its component parts: an agent's intentions and plans. In 1970 he published The Nature of Human Action, a foundational anthology with three introductory essays of his own entitled, "Action and Behavior," "Ability, Possibility, and Power," and "The Logic of Action" (Brand, 1970, pp. 3-21, 123-138, and 219-235). Citing a philosophical interest dating back to the ancient philosophers Plato and Aristotle, Brand wrote, "It is not an exaggeration to say that we are now in the midst of 
an action theory revolution," and advocated for broadening the scope of action theory beyond traditional theories in behavioristic psychology and philosophy of mind (Brand, 1970, p. i). Various essays sought to distinguish the difference between two so-called "action-locutions," i.e., the ordinary language phrases, "A person performs an action" and "A person can perform an action." Not merely a semantic difference, this type of analysis motivated philosophers to delve into the nature of physical and mental actions, including a person's motivations and resulting consequences. Such exploration, however, functioned at an abstract - or "conceptual"-level that generally ignored real-life application, as evidenced by Brand's matter-of-fact statement, "a theory about the nature of action is logically prior to explanatory, metaphysical, epistemological, ethical, and meta-ethical theories about action” (Brand, 1970, p. 4). A typical example of a basic action worthy of study was that of a person's raising his arm-action $a$-analyzed logically in terms of necessary and sufficient conditions. Consider, for example, the definition of the term "naïve behaviorism" which was considered an established starting point to action theory inquiry:

(D1) For every person $S$ and every action $a, S$ performed $a$ if and only if: (i) there is a $b$ such that $b$ is the appropriate bit of bodily or mental behavior of $S$ or there is a $b$ such that $b$ is the appropriate bit of bodily or mental behavior of $S$ and the appropriate effects of this bodily or mental behavior; and (ii) $b$ occurred (Brand, 1970, p. 5).

This definition is quoted at length to emphasize the distant starting point of Brand's progressive development from basic, abstract, conceptual action theory to the many actions he performed as president of two universities and of the NCAA "team" involving policy and people, more directly impacting student-athletes. Action theory required a look at bodily behavior, mental behavior (cognition), and when advancing beyond "naïve" behaviorism, the conative element of desires, plans, and intentions. If a philosopher of action theory today sought a challenging real-life example, she might consider the failure of four-time Olympic champion Simone Biles to perform basic actions that she knew she could perform by coordinating body and mind as she had hundreds of times before. At the August 2021 Tokyo Olympics, Biles withdrew from competition due to her inability to complete a series of actions that she had repeatedly performed in the past, clearly intended to perform again, but simply could not do: an affliction known by gymnasts as the "twisties;"

I seriously cannot comprehend how to twist . . . I have experienced them before. They're not fun to deal with . . . It's honestly petrifying trying to do a skill but not having your mind and body in sync. Could be triggered by stress I hear but I'm also not sure how true that is (Cooper, 2021, p. 1). Biles illustrates the difference between "I perform an action" and "I can(not) perform an action."

While at the University of Illinois at Chicago ("Circle," as it was called then), Brand edited The Nature of Causation (Brand, 1976) as well as a collection of essays entitled, Action Theory: Proceedings of the Winnipeg Conference (Brand \& Walton, 1976). The Nature of Causation explored yet another basic, foundational concepttracked back to Aristotle as well as pre-Socratic philosophers-seen as essential to 
understanding our daily experiences "of free will, human action, time, laws of nature, empirical knowledge - indeed, almost every area of philosophical inquiry" (Brand, 1976, p. i). In the volume, an essay co-authored with Marshall Swain introduced the notion of "first principles" in which "acceptable principles governing the relations of causation, necessity and sufficiency," functioned as tautological, i.e., necessarily true (Brand \& Swain, 1976, pp. 348-349). An example was " $A$ causes $B$ only if $A$ and $B$ are distinct." In speeches as NCAA president, Brand often invoked "first principles," for example, the three "central" and "key" principles of "The Collegiate Model of Athletics" articulated in his 2006 State of the Association Address entitled, "The Principles of Intercollegiate Athletics." He referred to them as "axioms" that "should dictate the fundamental nature of college sports" as he examined each in detail:

Principle No. 1-Those who participate in intercollegiate athletics are to be students attending a university or college.

Principle No. 2-Intercollegiate athletics contests are to be fair, conducted with integrity, and the safety and well-being of those who participate are paramount.

Principle No.3 - Intercollegiate athletics is to be wholly embedded in universities and colleges (Brand, 2006a, p. 3).

It is important to realize their philosophical source and the weight of their importance. He saw them as basic_-obvious and indisputable_-assumptions upon which premises of an argument's conclusion, such as those of The Collegiate Model, could reliably and indisputably rest.

The turning point in Brand's thinking as an action theorist was a keynote address at a conference on Action and Responsibility entitled, "Philosophical Action Theory and the Foundations of Motivational Psychology," which showed his emerging practical nature and a growing concern for results at a time when applied ethics was already developing within the discipline of philosophy. Co-editors Bradie and Brand seismically shifted the scope of their project in publishing their work in a new series of books in applied philosophy. "These studies will investigate the implications of theories of metaphysics, epistemology, and ethics, as well as the human sciences, for social problems which require rational planning and decision making" (Bradie \& Brand, 1980, p. v). They forged a new path toward "social problems," arguing:

Applied philosophy is not a recent innovation. Its practical objective is echoed in a passage by Aristotle in the Nichomachean Ethics: 'We are inquiring not in order to know what virtue is, but to become good.' Theoretical inquiry has an essential place in the total enterprise, but the ultimate concern is with the implications for human action (Bradie \& Brand, 1980, p. v).

This was a pivotal redirection of focus which revealed that Brand may have enjoyed engaging in purely "theoretical inquiry" in his early work but only 12 years past graduate school, was ready to ground the "total enterprise" in the practical application of action theory to human action and ultimately (as evidenced by the title of the volume) the realm of "action and responsibility" (Bradie \& Brand, 1980, p. v). Traditional philosophy had become too narrow; Bradie and Brand sought to expand 
the dialogue to other participants whose points of view would both challenge and enhance standard philosophical action theory. This was the first time Brand deliberately expanded the (academic) audience for whom he wrote, encouraging others to do the same. Thus, as early as 1980, he encouraged "a unifying of forces . . . bridge building between motivational psychology and philosophical action theory" (Brand, 1980, pp. 1, 18).

Moreover, Brand broke with past theorizing on actions by invoking Aristotle - to whom he referred many times in subsequent writings - as a foundation for contemporary thinking that re-emphasized that virtuous behavior, i.e., being a good person, was the goal. In effect, he moved the examination of human behavior, its motivation and ramifications, into the realm of ethics. Clearly, he argued, it was not sufficient to merely know what virtue is, how the term is defined by philosophers in terms of necessary and sufficient conditions. Rather, one must move beyond an abstract, intellectual exercise toward the psychological reasoning behind why and how one ought to be virtuous (known in philosophy as the "is-ought" problem). To become good involves a process that takes repeated good behavior, according to Aristotle, but in the $20^{\text {th }}$ century, one should also study mental states, plans, decisions, goals, and resulting actions. In 2007, these very notions were applied to the concept of sportsmanship in Brand's NCAA State of the Association Address entitled, "In All, Fairness:"

Aristotle argued that one becomes virtuous by doing virtuous acts. That is, the underlying attitudes leading one to act virtuously begins by undertaking the right behaviors until they become habitual. The attitudes necessary for sportsmanship must be nurtured, taught and reinforced (Brand, 2007a, p. 7). Developing his thoughts further at the University of Arizona, Brand published Intending and Acting: Toward a Naturalized Action Theory which criticized recent philosophical writing in action theory as stagnant and uninteresting; his goal was to usher in a new phase that maintained past "systematic theorizing" about human action but also introduced "nonphilosophical work on human action," i.e., "the scientific study of action" (Brand, 1984, p. x). Invoking the work of psychologist William James (1890) as well as philosopher Daniel Dennett (1960s-70s) and cognitive scientist Jerry Fodor (1970s-80s), Brand sought to focus on the central systems of cognitive psychology and related disciplines, stating, "One of my goals is to focus attention on the philosophical foundations of the human output system" (Brand, 1984, p. xi). His efforts to bring attention to empirical issues delved into motivational psychology in order to promote, in his words, "the naturalization of philosophical action theory" (Brand, 1984, p. x). Within two years, he published The Representation of Knowledge and Belief, co-edited with Robert Harnish, linguistics professor at Arizona, that indicated both the growing multidisciplinary nature of his research as well as his enjoyment of conversing and collaborating with colleagues (Brand \& Harnish, 1986). As Dean of the College of Social and Behavioral Sciences, he created an innovative Cognitive Science program that brought together philosophy, psychology, and linguistics (and now also includes computer science and cognitive neuroscience). Finally, just before assuming the NCAA presidency, he wrote an es- 
say entitled, "Activity and Passivity," which could perhaps be read as his last fully philosophical work on action theory in that he again offered a review of recent theorizing, argued its shortcomings, and recommended a "correction" for future direction (Brand, 2003a). Philosophers still debated his suggestions within the field of action theory, metaphysics, and cognitive science. Brand, however, had moved on.

\section{From Applied Philosophy to Action}

Following his writings in action theory, Brand - as Provost of Academic Affairs at The Ohio State University from 1986-1989 - began to write about the moral role of education in forming virtue, creating a model of character, a good person. This was another form of applied philosophy in which theoretical inquiry about learning was expanded to a broader audience of educators, both local and nationwide, and turned into administrative actions by means of a new leadership position within the academy. More pointedly was the administrative challenge to provide opportunities for all students (the enrollment at OSU then numbered 58,000), including those who were underrepresented in higher education and perhaps disadvantaged in K-12 in striving to achieve collegiate success. Three years into the role, a speech entitled, "Remarks by Myles Brand to Statewide Conference on Retention of Minority Students" was a seminal statement of his awareness of social injustices inherent in the system:

This year marks the $25^{\text {th }}$ anniversary of the Civil Rights Act. Title VI of this Act covers the admission of students to any federally funded institution of higher learning and its programs. This legislation was a major step in making higher education accessible to members of minority groups who previously had been denied admission to the college or university of their choice because of their race, color, or national origin. The passage of this act was not just a legal victory. It was a moral victory for all of us. (Brand, 1989, p. 1).

Brand cited the role of colleges and universities - their faculty, staff, and students in the "long-overdue guarantee of educational rights" that "demonstrated moral and social commitment and leadership" (Brand, 1989, p. 1). This claim went far beyond his vague observation in the early 1960s of "how important teachers are and what faculty members can accomplish in working with young people" to introduce and implement more complex goals that demanded an acknowledgement of human rights within an ethical framework, a deliberate moral and social commitment, and leadership (Lawrence, 2006, p. 57). The speech confronted two problems: high attrition rates for minorities in four-year colleges and low admission rates, especially in graduate and professional programs. "If we do not develop and implement successful strategies for addressing this now, we will feel the social, political, and economic consequences for generations" (Brand, 1989, p. 2).

Without hesitation, Brand blamed the U. S. government's low prioritizing of affirmative action policies under former President Ronald Reagan, "prominent politicians" who failed to speak out in a national commitment to Blacks, Hispanics, 
and members of other underrepresented groups, and the erroneous "impression that equality in our society is now an accomplished fact" (Brand, 1989, p. 2). He also noted that "today's students do not appear to have as strong a sense of social conscience as did students in the 1960s" (a time of folk music, hippies, and civil rights - all of which also influenced his professional administrative outlook) (Brand, 1989, p. 3). He proposed a solution at the critical point when students were dropping out:

Rather than responding to charismatic social and political leaders, we in higher education must ourselves be leaders ... We must take a moraland yes practical — position that diversity should be encouraged and valued. Then we must make certain that it is (Brand, 1989, p. 3).

It takes no giant leap of imagination to understand why only 14 years later, Brand would relish the opportunity to lead the NCAA and its diverse student body toward the goal of graduation while condemning "the dumb jock myth" (Brand, 2008d). In a data-driven prediction, he told administrators and staff assembled from various campuses, what would come to pass:

In 1985, minority children accounted for 20 percent of this country's schoolage population. By the year 2000, one-third of the school-age population is expected to be members of minority groups. By the year 2020, it will be nearly 40 percent. Institutions of higher education must show leadership now, if increasing numbers of these young people are to receive college degrees (Brand, 1989, p. 4).

Then he cited low numbers of Hispanics in college, declining numbers of Blacks, and "alarming statistics" of Black faculty among whom Ph.D. awards had dropped $27 \%$ since the mid-1970s and who thus provided even fewer role models for Black students than before (Brand, 1989). He never once mentioned intercollegiate athletics but we can fast-forward to the year 2021 - where the total number of athletes at 504,619 is made up of only $16 \%$ black, $20 \%$ other (including, among other groups, American Indian/Alaskan Native, Asian, Hispanic/Latino, and Native Hawaiian/Pacific Islander) while still 63\% white (NCAA, 2021). We can speculate that he viewed the opportunity to lead the NCAA as president beginning in 2003 as part of an ongoing commitment of moral leadership devoted to providing equal access to opportunity and diversifying the student body, i.e., a form of improving systemic social justice for student-athletes. Minority undergraduate students must be retained, he wrote in 1989, with "a positive, nurturing environment in which they are encouraged to reach their full potential ... a college education" (Brand, 1989, p. 6), devoid of discrimination and racism. With educational leaders working together, nationwide, he predicted success. He shared with his audience specific actions he had already taken at OSU, such as the creation of a Young Scholars Program, a "statewide early intervention program for students in middle and high school" that brought together hundreds of students from urban Ohio communities and which was expected to grow (Brand, 1989, p. 15).

As president of the University of Oregon, Brand prominently invoked a major tenet of Aristotle's ethics in his 1992 publication, "Undergraduate Education: Seeking the Golden Mean." Addressed to a national faculty audience, Brand cast 
the professor's dilemma of conflicting missions at institutions of higher learning as that between duty to publish-or-perish and the obligation to teach. Noting that "undergraduate education no longer possesses its old cachet," he urged, "This is something we need to change, and soon" in order to successfully revitalize undergraduate education: "We need to cultivate what Aristotle called the Golden Mean . . . by bringing the values and rewards associated with research and instruction into better alignment" (Brand, 1992, p. 18). Brand cited the "Oregon Model"- - conceived at the university through "a strategic planning process and much discussion (some of it contentious) ... in an attempt to provide a number of structures that support high-quality undergraduate education" (Brand, 1992, p. 26). Small Freshman Interest Groups (FIGS) and faculty incentives and awards were cited. The overall plan balanced "the research portion of our missions with instruction and public servicein short, reemphasizing Aristotle's Golden Mean” (Brand, 1992, p. 26).

In 2007, as NCAA President, Brand introduced listeners to Aristotle's Golden Mean in a Mondays with Myles podcast (Brand, 2007c) and in 2008, in his NCAA State of the Association address, he cited the ideal of balance to solve the problem of exuberant "fan interest" resulting in celebratory riots, harm to persons and property, and mob behavior:

Aristotle's Golden Mean of virtue being a balance between extremes is again appropriate. Too little engagement in the community fails to yield the positive effects and too much engagement detracts from the central academic mission of the university. Each university, in its own environment, must find the proper balance point (Brand, 2008b, p. 9).

When Brand became President of Indiana University, he expressed his thoughts in a speech entitled, "Higher Education and Obligations to the Future: The Inaugural Address of Myles Brand." Assuming the leadership of a university that was steeped in 175 years of history, Brand pledged his commitment - considering it his "moral duty" - to the success of future generations by emphasizing the fulfillment of one's obligations of trust as well as educational and cultural opportunities for students (Brand, 1995). He stressed the sciences, the humanities, and the arts, reminding those in attendance of his favorite philosophy professor at RPI who introduced him to Plato, Aristotle, Hume, Wittgenstein, and Russell:

Those heady days are still a part of my life; they remain essential to who I am, as a faculty member in philosophy and as a person . . . through the medium of teachers, we fulfill the greater part of our obligations to future generations (Brand, 1995, p. 7).

More specific was a presentation Brand (while still President of Indiana University) delivered several years later to a counseling center at Clarion Health Partners, entitled, "Lifting Up Our World: How Moral Values Affect the Way We Educate Our Young People.” Explicit values such as respect, harmony, beauty, and excellence were listed for the instruction and well-being of young people: values carried over into many of his NCAA speeches in the $21^{\text {st }}$ century, as he asked, "What truths or principles should they live by - what values ought they hold on to as they face the new millennium?" (Brand, 1998, p. 372). He cited an age of transition-extensive 
world travel, scientific discoveries - and a time in which "we've redefined gender roles more basically than they have been reshaped in any corresponding period in the past twenty centuries" (Brand, 1998, p. 371). He urged those present to teach students to be caring and compassionate, but he advised against giving them readymade or outdated answers; rather, we should equip them with "the tools to ask the right questions (Brand, 1998, p. 372). Once again, he invoked his academic background: "As a professional philosopher, I have dedicated my life to the belief that asking the right questions is as important as finding the right answers" (Brand, 1998, p. 372). Universities are places that are "uniquely well suited to lift up our society by giving people the tools they need to become moral and productive citizens," whereby "Moral reasoning is not memorizing and reciting dictums, but rather, it is reasoning from first principles" (Brand, 1998, p. 372). He cited philosopher Immanuel Kant's categorical imperative (from the $19^{\text {th }}$ century) - one should treat other people as ends, rather than as means - as "the best bedrock" for both personal and business practices and encouraged the cultivation of a "moral imagination" in order to "help us reflect on the consequences of our actions;" for "the very purpose of ethics . . is to preserve the ability of spiritually healthy and intellectually vital people to work together in harmonious relationships. That sort of relationship requires both wisdom and virtue" (Brand, 1998, pp. 374, 372). Brand urged the creation of organizations in both business and education "based on this magical combination of human values, organizations that speak both to our nobility and our humility . . . to make the world a better place, a place populated by caring, respectful people, not those prone to violence" (Brand, 1998, pp. 374). Five years later, one such organization Brand came to lead was the NCAA.

These early words are worth studying for their attention to the role of ethics and moral values conveyed through applied philosophy: the application of philosophical method, principles, and debate to contemporary social problems that needed solving by an administrator hired to solve them. When Brand became national news himself in 2000 during a particularly difficult period at Indiana University prior to his presidency at the NCAA, he cited ethics as a guide. Following a tense probationary period over the summer months of 2000 for the basketball coach, Bob Knight, Brand fired him for violating a "zero tolerance policy" that prohibited unwelcome behavior toward any student, staff, or faculty member on campus. The process officially began in the spring with the results of a seven-week investigation into Knight's behavior toward student Neil Reed - whom he grabbed by the throat during practice - and the imposition of a "zero tolerance" policy on May 15, 2000. Knight was warned with a document entitled, "Sanctions and Directives Resulting from the Conditions for Review" (Brand, 2000a, p. 5). Often overlooked by the media was the fact that Knight had explicitly agreed to that legal document (Brand 2000a, p. 4). Brand was severely criticized by faculty, the press, and the general public for allowing Knight one more chance over the summer while Knight and his fans resented the restrictive policy. One hundred and seventeen days later, Knight's verbal interaction and touching of an Indiana University Bloomington student explicitly violated the sanctions to which Knight had agreed and days later, he was relieved of his coaching duties by Brand. 
In a subsequent ESPN interview, Knight denied knowing what exactly the sanctions meant, claiming that no one, not even his lawyer, had explained them to him. Reminiscent of standard philosophical definitions, Brand had defined "zero tolerance" in necessary and sufficient conditions. Knight's claim was unfounded.

Brand was criticized again, primarily by Knight fans and the media, for the termination of the coach's 29-year contract (The Indiana University governing Board of Trustees fully supported Brand in this decision; otherwise, Brand could have been fired). The Knight Termination Press Conference held at the Indianapolis campus on Sep. 10, 2000, numbered over two hundred sports writers and reporters and included 27 television cameras. Despite both media and fan outcry to his imposed zero tolerance policy on Knight, Brand stated, "I believed then, and I believe today, that it was ethical and proper to give the coach this final opportunity" (Brand 2000b, p. 1). In referring to his decision as "ethical" and "proper" Brand sought to contextualize and validate his decision within the framework of his governing principles and logical decision-making process as applied to a real-life "social problem." He performed the difficult action of removing the coach from campus to protect student-athletes on the basketball team as well as all other students, and to ensure the integrity of Indiana University in its mission of providing a safe environment for students to learn, grow, and succeed.

After Knight's firing, Brand made university history by appointing as interim and then permanent head coach an assistant coach to Knight, Mike Davis. Davis became Indiana University's first African American head basketball coach and indeed, the first African American coach in intercollegiate athletics ever hired in the school's history. There was pushback on this hire, much of it racist in tone. This action was in overt defiance of unspoken tradition on the Bloomington campus and beyond: a beautiful campus in a small southern Indiana town where just a short drive into the country revealed Confederate flags flying. ${ }^{3}$ It caused numerous sports writers to disparage Coach Davis's credentials despite that fact that the following year he led the team to the final game of the 2002 NCAA Division I Men's Basketball Championship. At playoff games (which Brand attended with a police escort), hostile Knight fans would bellow that the reason the Hoosiers kept advancing during March Madness was because former Coach Knight's team had been kept intact by Coach Davis. In effect, they claimed, the team had been stolen from Knight and handed over to an assistant coach — who, Knight said, was not an "Indiana guy" (Davis, 2021). The Hoosier run to the 2002 Final Four was historic beyond just the keen competition and enjoyment of the games; Indiana eventually lost to Maryland, but history had been made.

I would argue that the hiring of Coach Davis was one of the most significant moments in Brand's administrative career that reinforced and compelled the urgency of future work on what he had earlier called "social problems" - what we now call "issues of social justice." Confronted with unfiltered racism and hatred, the epitome of unsportsmanlike conduct (students marched on our university residence, hung his image in effigy from dorms and frat houses, and issued death threats), he stood strong in the action he had taken. ${ }^{4}$ In his role as President of the NCAA, his insistent pro- 
motion of justice - in the form of the hiring of African Americans and other minority coaches, along with women administrators-never waned. He routinely expressed frustration with the lack of success nationwide but continued to instigate new programs to improve the numbers and the work environment, e.g., by hiring the first Vice President of Diversity and Inclusion Charlotte Westerhaus-Renfrow, as well as Executive Vice President of Education and Community Engagement and Chief Inclusion Officer Bernard Franklin (whose essay co-authored with C.K. Harrison is included in this special issue). Sports fanatics continue to cite the firing of Knight as newsworthy, but it was the hiring of Coach Davis that set an institutional precedent, brought attention to the ongoing but ignored systemic injustice of preferential hiring practices, and set Brand on a course of action to do more on behalf of minority hires and promotions. As he had acknowledged in his 1989 speech at The Ohio State University, young Black student-athletes needed role models and even in 2003-2009, young Black coaches were still not being given a fair chance. Future scholars may debate the ethics and business sense of the Davis hire - his success waned after his 2001-2002 season - but overall, the numbers do not lie. Brand was aided in his efforts to continue measuring student success and hiring practices by utilizing data collected by both the NCAA and Dr. Richard Lapchick, Chair of the DeVos Sport Business Management Graduate Program in the College of Business Administration at the University of Central Florida and Director of its Institute for Diversity and Ethics in Sport (TIDES). With numbers and charts, the evidence was undeniable, particularly in sports like men's basketball and football where students of color comprised over $50-60 \%$ of the team but coaches of color numbered in the single digits. As debate arose over whether to follow the NFL Rooney Rule, the NCAA instituted measures to improve the numbers. Brand himself admitted that solving this problem was one of the most persistent and frustrating challenges of his tenure: one that even to this day reveals a nagging resistance to racial equity. In an op ed, Brand argued that diversity hiring was simply the right and smart thing to do (Brand, 2009d). It was Lapchick who wrote in a tribute to Brand for ESPN.com on Thursday, September 17, 2009: "America lost a champion for student-athletes, for Title IX and for civil rights in sports with the passing of Dr. Myles Brand on Wednesday. No one did more to make college sport live up to its ideals" (Lapchick, 2009, p. 1).

Shortly after the firing of Knight, Brand delivered his first address to the National Press Club in Washington, D.C. on January 23, 2001. And the rest, as they say, is history - or rather, legacy - which is under scholarly scrutiny in this special issue. Brand cited the long-standing call from the John S. and James L. Knight Commission on Intercollegiate Athletics for academic reform within intercollegiate sports, labelling his plan "Academics First." He warned about the rising commercialization of sport - a theme that grew stronger over the years - and moved him to argue that "the central issue is not to find a way to dismantle intercollegiate athletics, but rather to effectively limit its excesses so that its positive features can flourish" (Brand 2001a, p. 369). Aristotle's Golden Mean was invoked to justify balance. Most often quoted in the press was the phrase, "While we don't want to turn off the game, we can lower the volume" (Brand 2001a, p. 371). Calling further attention to the topic, he published an essay, "Academics First: Rejuvenating Athletics Reform," in 
the March/April 2001 publication of the AGB (Association of Governing Boards of Universities and Colleges) Trusteeship, a governing body with whom he would later work closely to draft guidelines for the balanced operation of intercollegiate athletics on campuses (Brand, 2001b). In the Fall 2002 issue of The Presidency published by the American Council on Education (ACE), he wrote an essay entitled, "The ENGAGED President: Changing Times, Unchanging Principles." Quoting a favorite $20^{\text {th }}$ philosopher, Brand wrote:

As Bertrand Russell pointed out, 'Change is one thing, progress is another. Change is scientific. Progress is ethical. Change is indubitable, whereas progress is a matter of controversy.' We can make progress, in Russell's sense, only if we develop a sense of mission and cohesion that unites the university's various constituents and expresses the core values of the academy. It is these core values that will sustain us in the midst of the controversies that accompany change. And we must develop policies and partnerships that nurture progress. These are both moral and prudential obligations for higher learning (Brand, 2002, p. 30).

Ironically, the time of the publication was contemporaneous with the NCAA search for a new president. To date, no university president had ever been chosen for that position. It indeed became a "changing time" for Brand as he assumed the NCAA presidency on January 1, 2003.

\section{Legacy of Moral Leadership: "A Friend in the Justice World" (Lapchick, 2009)}

How did Brand advise and lead over one thousand constituents of the NCAA to make ethical, albeit controversial progress, when guided by "both moral and prudential obligations?"

Visions can't be imported. They have to be homegrown. I always found that it took about a year, one cycle, to really understand the depth and the subtlety of an institution (Lawrence, 2006, p. 62).

This strategy, which usually brought success or at least reluctant acknowledgement by the unpersuaded that their voices had been heard and seriously considered, was imported to the NCAA.

Once I understood what its [the institution's] aspirations were and what was possible in terms of its strengths, then I would let a vision emerge. I would constantly test and retest that vision. I'm a philosopher and philosophy is mostly done through dialectic debate, so I would formulate a position that I thought might work and I would go into a group to try it out. I wanted people to argue with me. Could I defend this position? Did this make sense?

Did they have objections? That's the process (Lawrence, 2006, p. 63).

The key, however, was in the scope of the vision. In effect, Brand suggested, "What you've drawn out in the plan is actually their tacit aspirations" in that you lead them to discover, acknowledge, and then expand beyond their own original goals (Lawrence, 2006, p. 65). 
It just takes time and you have to be patient with it. But at the end of the process, there emerges a future vision of the institution that is consistent with and indeed underlies what its members want it to become but is more than they are currently able to reach. The vision of the future has to be a stretch, something more than they had in their minds when they started (Lawrence, 2006, p. 63).

In his first NCAA State of the Association Address in January, 2003 (when he had been on the job less than two weeks), Brand identified two guideposts - reform and advocacy - promising the NCAA constituency and the media that "The future directions of intercollegiate athletics must reflect our positive values. Our reform goal should be enhancing the academic and developmental environment necessary for the full success of student-athletes. In the end, it is all about the student-athlete" (Brand, 2003b, p. 2). Also in early 2003, he presented the Title IX Seminar Keynote Address, immediately advocating in his NCAA tenure for female student-athletes, female coaches, and women of color, partially in response to U. S. Secretary of Education Rod Paige's 15-member Commission on Opportunity in Athletics that sought to undercut Title IX; in response, Brand said, "Title IX is not broken, and it does not need to be fixed" (Brand, 2003c, p. 6). By 2004, he was clearly advocating "a value-based vision of intercollegiate athletics" (Brand, 2004, p. 2). In 2005, he argued for fairness and equity, diversity and inclusion, within the hiring practices of college sports; "I can find no moral justification for excluding from serious consideration qualified persons who are not of the over-represented race or gender" (Brand, 2005a, p. 1). Again, he followed words with action; in August, 2005, he created the Office for Diversity and Inclusion led by an African-American scholar, Charlotte Westerhaus (now Westerhaus-Renfrow), to develop and implement strategies, policies, and programs such as the Diversity Education Program, the Football Coaches Academy, and the Leadership Institute for Ethnic Minority Males and Females. Also in 2005, he took the unprecedented step of banning offensive Native American mascots which he cited as "a teachable moment . . . about how Native American Indians have been characterized and, in some cases, caricatured ... This is not about an effort to be politically correct. It is about doing the right thing" (Brand, 2005b, p. 1-2).

By 2006, he unequivocally stated, "The NCAA - the voice and conscience of college sports - has a distinctive obligation for normative leadership: leadership that is value-based" (Brand, 2006a, p. 2). He published his oft-cited 2006 essay, "The Role and Value of Intercollegiate Athletics in Universities," prompting at least one commentator, Lou Matz (in this special issue), to wonder why Brand had not advanced his conclusion regarding athletics as a practiced and performed activitysimilar to college majors like dance, theater, and music - even further: to push for it as a major on its own. Among other topics, Brand focused instead on the academy's prejudice for the mental over the physical, in contrast to Plato's teaching of the harmony and unity of mind and body in which "physical accomplishment was necessary for successful citizenship" (Brand, 2006b, p. 17). Perhaps this was because he was writing for an audience of philosophers, such as that of the Journal of the Philosophy of Sport, not an audience of the general public or other academics 
interested in sports. He was keenly aware of rhetorical differences - reserving a certain style of prose for the New York Times, USA Today, and the Huffington Post, that only minimally mentioned philosophical terms, tenets, and theories. In contrast, his publications intended for philosophers (beyond those on action theory which ended around 2003) invoked familiar debates within the field, such as mind versus body, knowing how versus knowing that, normative ethics, and ancient concepts of beauty. The latter two interests were featured in co-authored essays entitled, "The Beauty of the Game" (Peg Brand \& Myles Brand, 2007), and with Marshall Swain, "The True Nature of Cheating" (Swain \& Brand, 2008). One can observe differences in style by comparing the co-authored Swain and Brand essay on cheating with the Mondays with Myles podcast with NCAA intern Josh Centor entitled, "Cheating" (Brand, 2007d). Perhaps it is no coincidence that at the time of his passing Brand was drafting another co-authored essay with Swain on sportsmanship and a book of his own entitled, Myles Brand: Sports and Leadership.

Issues of social justice began to proliferate. In a co-authored "Statement by NCAA President Myles Brand and Rutgers University President Richard L. McCormick Regarding Comments by MSNBC's Don Imus," Brand defended the Rutgers University women's basketball team against a racist, misogynistic Imus rant (Brand \& McCormick, 2007b). In his 2008 NCAA State of the Association Address, "Leadership and Challenges: The Roles of Intercollegiate Athletics in the University," he doubled down on rectifying injustices:

If intercollegiate athletics is to play its key role in higher education of helping promote social justice, as it should, then all of us, the NCAA national office and the over 1,000 universities it represents, must recognize the challenges and commit ourselves to meet them" (Brand, 2008b, p. 11).

He cited the lack of women in leadership positions, concluding, "it is simply incredulous that the talent pool is so weighted toward men to produce this imbalance. The facts, as well as the history of past lack of female representation, point to a continuing problem of injustice" (Brand, 2008b, p. 11). One month later, Brand addressed student-athletes from the Central Intercollegiate Athletic Association (CIAA), mostly Historically Black Colleges and Universities (HBCUs) attending their DII-level basketball tournament. After sharing his enthusiasm for their talents, he encouraged the values of teamwork, goal setting, hard work, self-sacrifice, self-discipline, self-awareness, and the pursuit of excellence, in other words, the reason he was an advocate of intercollegiate sports, namely, "the educational value in college sports" (Brand, 2008c, p. 3).

A lesser known but significantly important approach Brand advocated to augment the educational value in college sports was the actual study of sports, i.e., a position he endorsed in 2008 when the University of Oregon School of Law Resolutions Dispute Center shared news of a donation from then athletic director Pat Kilkenny and his wife to fund a new curriculum. The undergraduate courses, created under the rubric "Competition Not Conflict," were praised by Brand for using a multidisciplinary approach that would "bring to bear a wide range of methodologies and databases from discussions as well as a wide range of experiences" in the large- 
scale cultural phenomenon of college sports; he commented, "You'd miss much of the depth unless you use this approach" (Brand, 2008e). Brand clearly relished the creation of these classes at Oregon, as he conveyed at the time: "What I think is most important is, unlike many gifts to athletics, this one clearly recognizes the academic context in which intercollegiate athletics is conducted" (Brand, 2008e). He saw the study of sport at the college level as a unique opportunity to

emphasize the values underlying the conduct of sport: sportsmanship, respect and civility toward others, and the ability to grow as a person through participation ... In college, winning is important but it's more than that. It's how you participate ... How you conduct yourself and what values you're representing (Brand, 2008e).

He was specific about the "course objectives" of the classes and how they might appeal to students in general on campus, not just to student-athletes:

The studies that would be undertaken should help us understand how athletics could benefit participants as young as six and eight years old as well as weekend warriors . . . address deeper problems about college sports on campus including the developmental aspects ... [the] maturation process (Brand, 2008e).

Finally, Brand often emphasized in speeches and op eds the long-term benefits of sports:

Learning attitudes and values and developing life plans are an important aspect of growing while in college. There are many ways to obtain that growth and development. I think none does it better than athletics (Brand, 2008e).

As NCAA president in 2007, Brand had already taught a 400-level class at a nearby Indiana University campus called "Philosophy and Culture: Philosophy of Sports" in which he focused on college sports, the NCAA, and predictable topics such as the integration of athletics into institutions of higher education, including recent academic reforms; fiscal responsibility in college sports; amateurism and paying student-athletes for performance ("pay for play"); sportsmanship; the media's influence on college sports; equity in college sports, including Title IX and minority access; performance enhancing drugs; and the responsibility of intercollegiate athletics to widen social concerns, such as the use of Native American mascots. He missed the classroom and took the opportunity to teach and influence a class of Indianapolis students.

\section{Conclusion}

By 2007 - with graduation rates continually rising - Brand was touting a success story while simultaneously reminding the media to "get their facts right!" (Brand, 2007a, p. 2). He was quoted by former Indiana University football coach Gerry DiNardo as encouraging student-athletes, when he met with them in person on the practice field or in the locker room, to "One, graduate; two, graduate; and three, graduate" (DiNardo, 2007). 
In light of declining health-Brand was diagnosed with Stage IV pancreatic cancer on December 31, 2008 - a shortened version of his final State of the Association Address was publicly delivered by Vice President Wallace Renfro at the NCAA convention in January, 2009. In the longer printed version, Brand addressed "the major issue of the proper role for commercial activity within intercollegiate athletics" by advancing "A Balanced Approach" that again invoked Aristotle's Doctrine of the Golden Mean: a middle ground - "the balance point"- - between the two extremes of crass commercialism and unrealistic idealism (what he called "pure" athletics). Two new principles emerged: "(P1) Student-athletes are not to be exploited in commercial activity, and (P2) All commercial activity in intercollegiate athletics undertaken by universities and colleges, conferences and the NCAA national office must be consistent with the values and mission of higher education" (Brand 2009a, pp. 8-9). "These principles, in turn, must be translated into rules and practices, with appropriate sanctions" - a task to turn theory, i.e., principles, into action, i.e., practical guidelines for behavior - "Once that occurs, we will be able to move forward in the conduct of intercollegiate athletics with a clear conscience. Intercollegiate athletics has become an integral part of college life and culture. We must do it right" (Brand, 2009a, p. 9).

The agenda was set for 2009 and beyond with the "Final Report of the NCAA Task Force on Commercial Activity in Division I Intercollegiate Athletics" from the Executive Committee. Now open to much debate after the NCAA's shift to allow student-athletes to monetarily benefit from the selling of NILs (Name, Image, Likeness), the report stated unequivocally (1) Student-athletes cannot financially benefit from their participation in intercollegiate athletics beyond grants-in-aid and other forms of approved support allowed by NCAA regulations to promote student-athlete well-being, and (2) their motivation to play college sports should come primarily from the educational and physical benefits of participation (Brand, 2009b, pp. 1-2). It will take time - and scholarly study and debate - to assess the impact of NIL rulings on student-athletes. Already - months into the ruling - money managers are citing potential problems for young, inexperienced, and unprotected student-athletes (Sullivan, 2021).

The plan to reform college athletics included the introduction of new and unique data-gathering measures that would hold students, teams, coaches, presidents, and campus governing boards accountable for the academic progress of student-athletes. Brand argued that the goal of the college experience is graduation and so the NCAA devoted its attention to charting accurate data on student-athlete success in the form of Academic Progress Rates (APR) that measured team performance (any team averaging below 930 now incurs disincentives or punishments) as well as Graduation Success Rates (GSR) for Division I and the Academic Success Rates (ASR) for Division II. The rate of $74 \%$ in 2003 was established. An unofficial goal of $80 \%$ for the future was set. After six years working on improving graduation rates of student-athletes, Brand announced in the summer issue of the NCAA Champion Magazine, "APR: Mission Accomplished!" (Brand, 2009c, p. 5). After starting at $74 \%$, the stated goal of $80 \%$ had been reached; he had succeeded in debunking Myth 
\#1 - college sports is more about sports than college — by challenging and changing the environment for college athletes (Brand, 2005a). A recent update of the history of GSRs for student-athletes showed the D1 GSR rate had reached 90\%! (see Figure 1). Brand would certainly have been happy to see that number (Hosick, 2020).

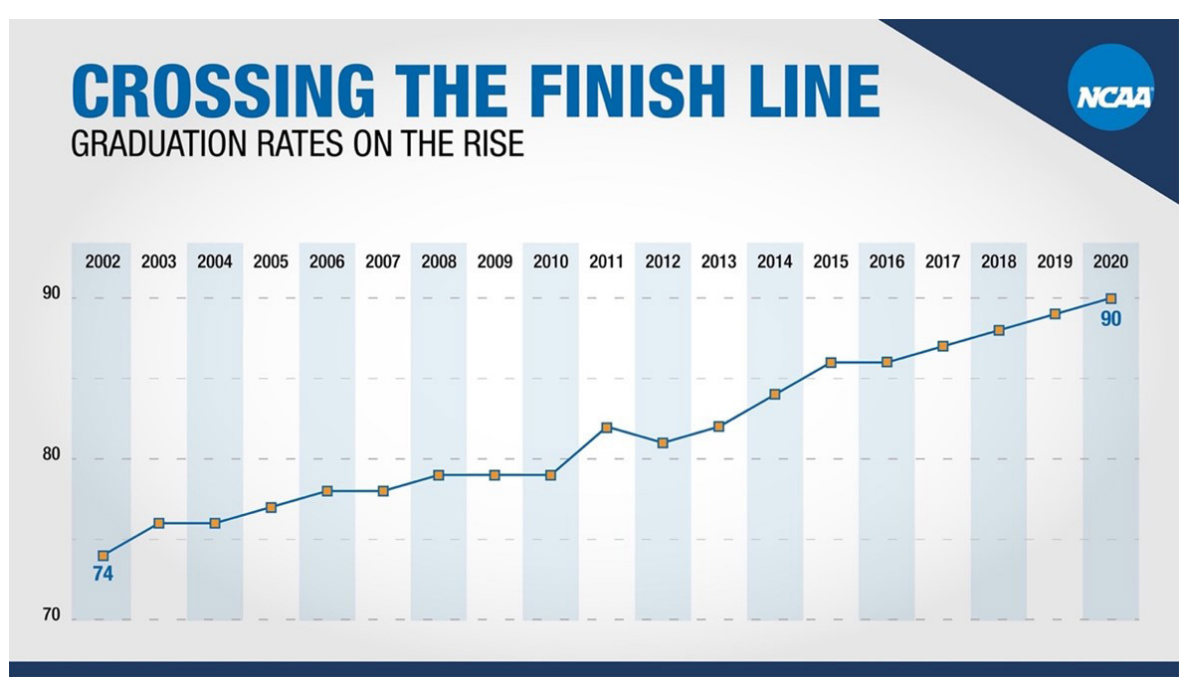

Figure 1

DI student-athlete graduation rate. In Hosick, M.B. (2020, November 17). DI college athletes reach $90 \%$ graduate rate; Rate for men's basketball student-athletes climbs 4 percentage points. NCAA. Used with permission. https://www.ncaa.org/about/resources/media-center/ news/di-college-athletes-reach-90-graduation-rate

Brand offers a cogent and workable characterization of leadership, particularly moral leadership and leadership by consensus. Brand's inclusion of his background and training in philosophy and cognitive science emphasized logical reasoning, imaginative speculation, psychological persuasion, and action based on moral principles. In addition, he promoted transparency: discussing new ideas out in the open, gathering feedback, debating, and then crafting a vision together. When asked directly, he defined leadership as "the ability to see ahead and put things in global context, to identify with the aspirations and the values of the institution, to take personal responsibility, and frankly, to work hard" (Lawrence, 2006, p. 69). Having weathered the adventure of NCAA leadership, he has left us much to ponder.

\section{Notes}

1 A special note of gratitude is conveyed to R. Scott Kretchmar for his collaborative work with Myles Brand, his initiative in becoming the Founding Editor—now Editor-in-Chief Emeriti—of this journal and for being a most willing and agreeable co-editor, mentor, and friend. 
${ }^{2}$ Many references can be found at www.mylesbrand.com, a website edited and launched by Peg Brand Weiser in February 2021, with thanks to Indiana University Archives and the NCAA.

${ }^{3}$ Rock musician John Mellencamp, an avid supporter of IU, especially its sport programs, grew up nearby; he is well-known for his 1985 song, "Small Town." At the university commencement ceremony in 2000, he became Dr. John Mellencamp with the conferring of an Honorary Doctorate Degree in Music by Brand, then President of IU.

${ }^{4}$ To correct the record of false stories that have been propagated, for instance, by Martha C. Nussbaum in a chapter of her 2021 book, Citadels of pride: Sexual assault, accountability, and reconciliation, entitled, "Masculinity and corruption: The sick world of college sports" (p. 210), I never stopped teaching my classes. This is just one of several errors or omissions in the Nussbaum publication despite information I provided to her.

\section{References}

Bradie, M., \& Brand, M. (1980). Philosophical action theory and the foundations of motivational psychology. In M. Bradie, \& M. Brand (Eds.), Action and responsibility (pp. 1-19). Bowling Green Studies in Applied Philosophy, Volume II.

Brand, M. (Ed.). (1970). The nature of human action. Scott, Foresman and Company. Brand, M. (Ed.). (1976). The nature of causation. University of Illinois Press.

Brand, M., \& Swain, M. (1976). On the analysis of causation. In M. Brand (Ed.), The nature of causation (pp. 346-351). University of Illinois Press.

Brand, M., \& Walton, D. (Eds.). (1976). Action theory: Proceedings of the Winnipeg Conference. D. Reidel Publishing Co.

Brand, M. (1984). Intending and acting: Toward a naturalized action theory. MIT Press/Bradford Books.

Brand, M., \& Harnish, R.M. (Eds.). (1986). The representation of knowledge and belief. The University of Arizona Press.

Brand, M. (1989, January 11). Remarks to statewide conference on retention of minority students at The Ohio State University. https://mylesbrand.com/wp-content/uploads/1989/01/1989-Retention-of-Minority-Students.pdf

Brand, M. (Fall, 1992). Undergraduate education: Seeking the Golden Mean. Educational Record (The Magazine of Higher Education), 73(4), 18-26. https:// mylesbrand.com/wp-content/uploads/1992/01/1992-Undergrad-Ed-Seekingthe-Golden-Mean.pdf

Brand, M. (1995, January 19). Higher education and obligations to the future: The inaugural address of Myles Brand. Indiana University. https://mylesbrand.com/ wp-content/uploads/1995/01/1995-IU-Inaugural-Address-1-19-1995.pdf

Brand, M. (1998, November 19). Lifting up our world: How moral values affect the way we educate our young people. Delivered to the Buchanan Counseling Center at Clarion Health Partners, Indianapolis, Indiana. Published in Vital Speeches 
of the Day, https://mylesbrand.com/wp-content/uploads/1998/01/1998-LiftingUp-Our-World-Moral-Values.pdf

Brand, M. (2000a). Indiana University news conference on Coach Bob Knight sanctions, including Sanctions and directives resulting from the conditions for review and the agreement signed by Knight (May 14, 2000). https://mylesbrand.com/ wp-content/uploads/2000/01/2000-5-15-Brand-IU-News-Conference-KnightSanctions.pdf

Brand, M. (2000b). Brand IU Letter-Knight firing (2000, September 13). https:// mylesbrand.com/wp-content/uploads/2000/01/2000-9-13-Brand-IU-LetterKnight-Firing.pdf

Brand, M. (2001a). Academics first: Reforming intercollegiate athletics. National Press Club, Washington, D.C. (January 23, 2001), published in Vital Speeches of the Day. https://mylesbrand.com/wp-content/uploads/2001/01/National-PressClub-2001.pdf

Brand, M. (2001b, March/April). Academics first: Rejuvenating athletics reform. AGB (Association of Governing Boards of Universities and Colleges) Trusteeship, 9(2), 18-22. https://mylesbrand.com/wp-content/uploads/2001/01/2001Academics-First-Rejuvenating-Athletics-Reform-Mar-Apr.pdf

Brand, M. (2002, Fall). The engaged president: Changing times, unchanging principles. The Presidency 5(3), 27-30.

Brand, M. (2003a). Activity and passivity. In M. Sintonen, P. Ylikoski, \& K. Miller (Eds.), Realism in action (pp. 99-111). Kluwer Academic Publishers.

Brand, M. (2003b, January 12). 2003 NCAA State of the Association address. https:// mylesbrand.com/wp-content/uploads/2003/01/2003-NCAA-State-of-theAssociation.pdf

Brand, M. (2003c, April 28). NCAA Title IX Seminar keynote address. https:// mylesbrand.com/wp-content/uploads/2003/01/Brand-NCAA-Title-IXKeynote-Address-2003.pdf

Brand, M. (2004, January 11). Value-based educational model. 2004 NCAA State of the Association Address. https://mylesbrand.com/wp-content/uploads/2004/01/ 2004-NCAA-State-of-the-Association.pdf

Brand, M (2005a, January 8). The myths of college sports: Debunking the four great commonly held misperceptions about intercollegiate athletics. 2005 NCAA State of the Association Address. https://mylesbrand.com/wp-content/uploads/ 2005/01/2005-NCAA-State-of-the-Association.pdf

Brand, M. (2005b, August 11). NCAA takes high road with ban of offensive mascots. USA Today. https://mylesbrand.com/wp-content/uploads/2005/01/2005-NCAATakes-High-Road-USA-Today-811-2005-.pdf

Brand, M. (2006a). The principles of intercollegiate athletics. 2006 NCAA State of the Association Address. https://mylesbrand.com/wp-content/uploads/2006/01/ 2006-NCAA-State-of-the-Association.pdf

Brand, M. (2006b). The role and value of intercollegiate athletics in universities. Journal of the Philosophy of Sport, 33(1), 9-20. https://mylesbrand.com/wp-content/ uploads/2006/01/The-Role-Value-of-Intercollegiae-Athletics-in-Univ-2006.pdf 
Brand, M. (2007a). In all, fairness. 2007 NCAA State of the Association Address. https://mylesbrand.com/wp-content/uploads/2007/01/2007-NCAA-State-of-the -Association.pdf

Brand, M., \& McCormick, R.L. (2007b, April 6). Statement by NCAA President Myles Brand and Rutgers University President Richard L. McCormick regarding comments by MSNBC's Don Imus. Rutgers Website. https://mylesbrand.com/ wp-content/uploads/2007/01/2007-Rutgers-Univ-Joint-Statement-on-DonImus-4-6-2007.pdf

Brand, M. (2007c, April 9.). Aristotle’s Golden Mean. NCAA Mondays with Myles Podcast. $\quad$ https://mylesbrand.com/wp-content/uploads/2007/01/4-9-2007Aristotles-Golden-Mean.pdf

Brand, M. (2007d, October 8). Cheating. NCAA Mondays with Myles podcast. https://mylesbrand.com/wp-content/uploads/2007/01/10-8-2007-Cheating.pdf

Brand, M. (2008a, Fall). Play It Smart News and Notes. National Football Foundation \& College Hall of Fame, Inc.

Brand, M. (2008b, January 12). Leadership and challenges: The roles of intercollegiate athletics in the university. NCAA State of the Association Address. https://mylesbrand.com/wp-content/uploads/2008/01/2008-NCAAState-of-the-Association.pdf

Brand, M. (2008c, February 26). Central Intercollegiate Athletic Association (CIAA) keynote address. https://mylesbrand.com/wp-content/uploads/2008/01/2008CIAA-Keynote-Address.pdf

Brand, M. (2008d, November 9). The 'dumb jock' myth is dumb. Huffington Post. https://mylesbrand.com/wp-content/uploads/2021/02/11-9-2008-HuffingtonPost-Dumb-Jock.pdf

Brand, M. (2008e). Personal correspondence with the University of Oregon School of Law; see "Kilkenny gift launches competition not conflict," Appropriate Dispute Resolution Center 2008 Newsletter, 1-2.

Brand, M. (2009a, January 15). The challenges of commercial activity. 2009 NCAA State of the Association Address. https://mylesbrand.com/wp-content/ uploads/2009/01/2009-NCAA-State-of-the-Association.pdf

Brand, M. (2009b, January). Final report of the NCAA Task Force on Commercial Activity in Division I intercollegiate athletics. https://mylesbrand.com/wpcontent/uploads/2009/01/2009-NCAA-Final-Report-on-Commercial-Activity. pdf

Brand, Myles (2009c, Summer). APR: Mission accomplished. Champion Magazine (NCAA Publishing), p. 5. https://mylesbrand.com/wp-content/ uploads/2009/01/2009-NCAA-Champion-Mag-APR-Mission-Accomplished. pdf

Brand, Myles (2009d, April 10). Diversity hiring is right, smart. Huffington Post. https://mylesbrand.com/wp-content/uploads/2021/02/4-10-2009-HuffingtonPost-Diversity-II.pdf

Brand, P., \& Brand, M. (2007). The beauty of the game. In J. Walls (Ed.), Basketball and philosophy: Thinking outside the paint (pp. 94-103). The University Press 
of Kentucky. https://mylesbrand.com/wp-content/uploads/2007/01/BrandBrand-The-Beauty-of-the-Game-2007.pdf

Cooper, S. (2021, July 30). Simone Biles gave the biggest clue yet that her Olympics are over, saying she can't 'comprehend how to twist' right now. Insider. https:// www.insider.com/simone-biles-hints-her-olympics-is-over-on-instagramtwisties-2021-7

Davis, M. (2021). IndianaHQ. https://indianahq.com/mike-davis/

DiNardo, G. (2007, January 24). University presidents enabling the arms race in college sports. The Herald-Times.

Gray, D. (2008, March 17). Myles Brand interview. Indiana University Emeriti Oral History Project. https://mylesbrand.com/wp-content/uploads/2008/01/ Transcript-Interview-with-IU-Emeriti-Oral-History-Project-3-17-2008.pdf.

Hosick, M.B. (2020, November 17). DI college athletes reach 90\% graduation rate; Rate for men's basketball student-athletes climbs 4 percentage points. NCAA. https://www.ncaa.org/about/resources/media-center/news/di-college-athletesreach-90-graduation-rate

Lapchick, R. (2009, September 17). Brand: 'A friend in the justice world.' ESPN. com https://mylesbrand.com/wp-content/uploads/2009/09/9-17-2009-ESPNLapchick-Tribute.pdf.

Lawrence, F.L. (Ed.). (2006). Myles Brand Interview. In Leadership in Higher Education (pp. 56-85). Transaction Publishers. https://mylesbrand.com/wpcontent/uploads/2006/01/Leadership-in-HIgher-Ed-2006-MB-interview.pdf

Lederman, D. (2021, August 2). NCAA calls constitutional convention amid turmoil. Insider Higher Ed. https:/www.insidehighered.com/quicktakes/2021/08/02/ ncaa-calls-constitutional-convention-amid-turmoil

NCAA (2020, September). Membership composition. https://www.ncaa.org/ about/who-we-are/membership/composition-and-sport-sponsorship-ncaamembership

NCAA (2021, March). Demographics database by gender and race/ethnicity from school year 2019-2020. https://www.ncaa.org/about/resources/research/ncaademographics-database

Scarpino, P. (2007, March 8). Myles Brand first interview. Indiana University Randall L. Tobias Center for Leadership Excellence. https://mylesbrand.com/ wp-content/uploads/2007/03/Myles-Brand-First-Interview-3-8-2007.pdf

Sullivan, P. (2021, August 6). Student-athletes can now earn money. Here are the pitfalls. The New York Times. https://www.nytimes.com/2021/08/06/yourmoney/student-athletes-endorsements.html

Swain, M., \& Brand, M. (2008). The true nature of cheating. In Michael Austin (Ed.), Football and philosophy: Going deep (pp. 90-100). The University Press of Kentucky. 